\title{
Hubungan Tingkat Ansietas dengan Infeksi Saluran Pernafasan Akut pada Mahasiswa Kedokteran Universitas Andalas Angkatan 2015-2016
}

\author{
Aisyah Marwa Bilqis ${ }^{1}$, Yaslinda Yaunin ${ }^{2}$, Eryati Darwin ${ }^{3}$
}

\begin{abstract}
Abstrak
Ansietas merupakan gangguan alam perasaan ( affective) yang ditandai dengan perasaan ketakutan atau kekhawatiran yang mendalam dan berkelanjutan, tidak mengalami gangguan dalam menilai realitas, kepribadian masih tetap utuh, perilaku dapat terganggu tetapi masih dalam batas normal. Ansietas dapat menurunkan sistem kekebalan tubuh sehingga rentan untuk infeksi salahsatunya Infeksi Saluran Pernafasan Akut (ISPA). Tujuan penelitian ini adalah untuk mengetahui hubungan tingkat ansietas dan ISPA pada mahasiswa Fakultas Kedokteran Universitas Andalas angkatan 2015-2016. Penelitian ini merupakan studi analitik dengan desain penelitian kohort prospektif yang dilaksanakan dari November 2017 sampai Februari 2018 di Fakultas Kedokteran Universitas Andalas. Pengumpulan data menggunakan instrumen HRS-A kuisioner dan kuisioner ISPA kepada 257 mahasiswa angkatan 2015-2016. Pengambilan sampel menggunakan teknik stratified random sampling. Analisis data menggunakan analisis univariat dan analisis bivariat. Hasil analisis univariat didapatkan distribusi frekuensi tingkat ansietas yaitu $39,7 \%$ berada dalam keadaan tidak ansietas, 56,1\% mahasiswa mengalami ansietas ringan-sedang dan 4,2\% mahasiswa mengalami ansietas berat. Distribusi frekuensi infeksi saluran pernafasan akut yaitu 56,1\% mahasiswa mengalami ISPA dan 43,9\% mahasiswa tidak mengalami ISPA dalam 3 minggu terakhir. Simpulan studi ini adalah terdapat hubungan bermakna antara tingkat ansietas dengan infeksi saluran pernafasan akut pada mahasiswa Fakultas Kedokteran Universitas Andalas.
\end{abstract}

Kata kunci: tingkat ansietas, infeksi saluran pernafasan akut, HRS-A

\begin{abstract}
Anxiety disorder is marked by great fear and continuous worry without any disturbance in reality perception and personality but may impact individual behavior in minor scale. Anxiety could reduce immunity and make someone prone to get infection as likely as Acute Respiratory Tract Infection (ARTS). The objective of this study was to find the relationship between anxiety level and acute respiratory tract infection case on medical students of Andalas University batch 2015-2016. A cohort study was done using prospective approach, conducted on August 2017 to Januari 2018 in Medical Faculty of Andalas University. Data was collected by using HRS-A and ARTS questionnaires given to 257 students chosen with stratified random sampling technique. Univariate and bivariate data were analyzed. Univariate analysis showed the distribution of anxiety level was $39.7 \%$ no anxiety, $56.1 \%$ low-moderate level and $4.2 \%$ high level of anxiety while distribution of acute respiratory tract infection case was $56.1 \%$ having ARTS and $43.9 \%$ having no ARTS in the last 3 weeks. The conclusion is the significant relationship between anxiety level and prevalence of acute respiratory tract infection on medical students of Andalas University.
\end{abstract}

Keywords: anxiety level, acute respiratory tract infection, HRS-A

Affiliasi penulis: 1. Prodi Kedokteran Fakultas Kedokteran Universitas Andalas Padang (FK Unand), 2. Bagian Psikiatri FK Unand, 3. Bagian Histologi FK Unand
Korespondensi: Aisyah Marwa Bilqis, Email:

aisyahmarwabilqis@gmail.com, Telp: 081267624515 


\section{PENDAHULUAN}

Ansietas adalah kekhawatiran yang tidak jelas dan menyebar, yang berkaitan dengan perasaan tidak pasti dan tidak berdaya sehingga dapat mengancam keamanan individu tersebut.Keadaan emosi ini tidak memiliki objek yang spesifik. ${ }^{1}$ Gejala kecemasan dapat meliputi kesulitan untuk dapat beristirahat atau sering merasa gelisah, kesulitan untuk berkonsentrasi, irritability, perasaan tegang yang berlebihan, gangguan tidur, semuanya dapat diakibatkan karena kecemasan yang berlebihan. ${ }^{2}$

Setiap stressor merupakan penyebab individu mengalami ansietas, maka secara otomatis muncul upaya untuk mengatasinya dengan berbagai mekanisme koping. Ansietas perlu diatasi untuk mencapai keadaan homeostasis dalam diri individu, baik secara fisiologis maupun psikologis. Apabila individu tidak mampu mengatasi secara konstruktif, maka ketidakmampuan tersebut dapat menjadi penyebab utama terjadinya perilaku yang patologis. ${ }^{1,3}$

Mekanisme koping terhadap ansietas dapat diklasifikasikan ke dalam 2 kategori yaitu pertama, melalui strategi pemecahan masalah yang bertujuan mengatasi atau menanggulangi masalah/ancaman yang ada dengan kemampuan pengamatan secara realistik. Secara ringkas strategi pemecahan masalah ini bisa digunakan dengan metode STOP ( Source, Trial and Error, Others, serta Pray and patient). ${ }^{2,3}$ Kedua, dengan mekanisme pertahanan diri yaitu usaha untuk melindungi diri dari perasaan tidak adekuat. Ansietas merupakan keadaan psikiatri yang paling sering ditemukan di seluruh dunia. Penelitian yang dilakukan oleh Fuad et al pada mahasiswa preklinik kedokteran di Univeristi Putra Malaysia didapatkan 52\% mahasiswa mengalami ansietas. ${ }^{4}$ Penelitian sebelumnya oleh Wahed dan Hassan di Universitas Fayom pada 442 mahasiswa kedokteran menunjukkan hasil yang lebih tinggi yaitu didapatkan ansietas sebanyak $64,3 \%{ }^{5}$

Infeksi saluran pernafasan akut merupakan penyakit infeksi akut yang menyerang salah satu bagian atau lebih dari saluran nafas mulai dari hidung sampai kantung paru (alveoli) termasuk jaringan adneksa disekitarnya seperti sinus atau rongga disekitar hidung (sinus paranasal) rongga telinga tengah dan pleura. Sekitar 90-95\% penyakit ISPA disebabkan oleh virus ${ }^{6}$. Kejadian ISPA masih menjadi masalah utama di Indonesia. Data Dinas Kesehatan Padang tahun 2013 menunjukkan penyakit paling tinggi masih ISPA yaitu sebanyak 91.225 kasus. $^{7}$

Penyebab infeksi saluran pernafasan akut dapat berupa bakteri, virus, dan jamur. Bakteri yang banyak menyebabkan ISPA antara lain dari genus Streptokokus, Stafilokokus, Pneumokokus, Hemofilus, Bordotella, dan Korinebakterium. Virus antara lain golongan Miksovirus, Adenovirus, Koronavirus, Pikornavirus, Mikoplasma, dan Herpes virus. ${ }^{8}$ Sekitar 90-95\% penyakit ISPA disebabkan oleh Virus ${ }^{6}$ Belakangan ini diketahui bahwa boleh dikatakan semua mikroorganisme secara potensial dapat menimbulkan penyakit ISPA, bila sistem imunitas penderita semakin menurun. Penyakit ISPA masih merupakan penyakit utama penyebab kematian dan kesakitan bayi dan balita. Keadaan ini berkaitan erat dengan berbagai kondisi yang melatarbelakanginya, seperti malnutrisi, kondisi lingkungan baik asap atau debu dan sebagainya ${ }^{9}$.

Dalam keadaan sehat, tidak akan terjadi pertumbuhan mikroorganisme di paru. Keadaan ini disebabkan oleh adanya mekanisme pertahanan paru. Apabila terjadi ketidakseimbangan antara daya tahan tubuh,mikroorganisme dan lingkungan, maka mikroorganisme dapat masuk, berkembang biak dan menimbulkan penyakit. Adanya infeksi virus merupakan predisposisi terjadinya infeksi sekunder bakteri. Infeksi virus tersebut menyebabkan kerusakan mekanisme mukosiliaris yang merupakan mekanisme perlindungan pada saluran nafas terhadap infeksi bakteri, sehingga memudahkan bakteri patogen yang terdapat pada saluran nafas atas. ${ }^{10}$

Seseorang yang mengalami ansietas sangat rentan untuk menderita infeksi,salah satunya infeksi saluran pernafasan akut. Hal ini disebabkan oleh respon tubuh saat mengalami cemas. Respon sistem saraf otonom terhadap rasa takut dan cemas menimbulkan aktivitas involunter pada tubuh termasuk dalam mekanisme pertahanan diri. HPA axis adalah jalur utama dalam merespon situasi stress.dimana stress akan mengaktifkan hipotalamus yang selanjutnya akan mengaktifkan dua jalur utama stress, 
yaitu sistem endokrin (koreteks adrenal) dan sistem saraf otonom (simpatis dan parasimpatis). untuk mengaktifkan sitem endokrin, setelah hipotalamus menerima stimulus stress atau cemas, bagian anterior hipotalamus akan melepaskan Corticotrophin Releasing Hormone $(\mathrm{CRH})$, yang akan memberikan perintah pada kelenjar hipofisis untuk mensekresikan Adrenocorticotriopin Hormone (ACTH) ke dalam darah. $^{11}$

ACTH akan mengaktifkan zona fasikulata korteks adrenal untuk mensekresikan hormon glukokortikoid yaitu kortisol. Hormon kortisol ini selanjutnya akan berperan dalam proses umpan balik negatif yang dihantarkan ke hipotalamus dan kemudian akan diteruskan ke amigdala untuk memperkuat pengaruh stress terhadap emosi seseorang. Kadar kortisol yang tinggi dapat memberikan efek inhibisi terhadap produksi dan respon limfosit terhadap sitokin proinflamasi, menekan deferensiasi sel $\mathrm{T}$, aktivitas proses awal sel B dan diferensiasi monosit-makrofag. ${ }^{11}$ Kortisol juga akan menghambat migrasi polimorfonuklear, monosit dan limfosit ke daerah peradangan. ${ }^{12}$

Pengaruh ansietas terhadap sistem imun adalah akibat pelepasan neuropeptida pada limfosit B dan limfosit T. Kecocokan neuropeptida dan reseptornya akan menyebabkan terjadinya stres yang dapat mempengaruhi kualitas sistem imun. Beberapa penelitian imunologis menunjukkan stres menyebabkan penurunan respon limfoproliferatif terhadap mitogen (PHA, Con-A), aktifitas sel natural killer (NK) turun dan produksi interferon gama (IFN-) turun. ${ }^{11}$

Stress dapat terjadi pada siapa saja Mahasiswa fakultas kedokteran dalam kehidupan sehari-harinya tidak terlepas dari stress. Stressor adalah sumber stress dimana suatu keadaan, situasi objek atau individu tersebut dapat menimbulkan stress. Stressor pada mahasiswa kedokteran dapat bersumber dari kehidupan akademiknya, terutama tuntutan eksternal dan tuntutan akan harapannya sendiri.
Penelitian pada mahasiswa kedokteran di Fakultas Kedokteran Universitas Muhammadiyah Palembang, stress dapat terjadi dari Beberapa sisi, antara lain domisili mahasiswa (tempat tinggal yang jauh dari keluarga), masalah ekonomiseperti uang saku per bulan, prestasi akademik, beban tugas perkuliahan,hubungan interpersonal pada mahasiswa itu sendiri. $^{13}$

\section{METODE}

Jenis penelitian ini adalah analitik observasional dengan desain kohort prospektif untuk mengetahui hubungan tingkat anisetas dengan kejadian infeksi saluran pernafasan akut pada mahasiswa Kedokteran Universitas Andalas. Penelitian dilakukan dari November 2017 sampai Februari 2018 di Fakultas kedokteran Universitas Andalas dengan sampel mahasiswa FK Unand. Populasi adalah seluruh mahasiswa FK Unand prodi Kedokteran Angkatan 2015-2016. Teknik pengambilan sampel stratified random sampling. Analisis data pada penelitian ini adalah analisis univariat dan analisis bivariat. Analisis univariat untuk mengetahui distribusi frekuensi tingkat ansietas dan kejadian infeksi saluran pernafasan akut. Analisis bivariat untuk mengetahui hubungan tingkat ansietas dengan kejadian infeksi saluran pernafasan akut.

HASIL

Tabel 1. Karakteristik responden berdasarkan jenis kelamin

\begin{tabular}{ll}
\hline Jenis Kelamin & Frekuensi \\
\hline Laki-laki & 81 \\
Perempuan & 181 \\
\hline Total & 262 \\
\hline
\end{tabular}

Tabel 1 menunjukkan responden laki-laki sebanyak 81 orang dan responden perempuan sebanyak 181 orang. Responden terbanyak pada penelitian ini adalah responden perempuan. 
Tabel 2. Distribusi frekuensi tingkat ansietas

\begin{tabular}{lcc}
\hline Tingkat Ansietas & Frekuensi & $\%$ \\
\hline Tidak ansietas & 104 & 39,7 \\
Ansietas ringan- & 147 & 56,1 \\
sedang & 11 & 4,2 \\
Ansietas berat & 262 & $100 \%$
\end{tabular}

Tabel 2 menunjukkan sebagian besar dari responden dikelompokan dalam keadaan ansietas ringan-sedang $(56,1 \%)$, sebagian kecil dari responden dikelompokan dalam tidak ansietas $(39,7 \%)$, dan ansietas berat $(4,2 \%)$.

Tabel 3. Distribusi frekuensi kejadian infeksi saluran pernafasan akut dalam 3 minggu terakhir

\begin{tabular}{lcc}
\hline ISPA & Frekuensi & $\%$ \\
\hline Pernah & 147 & 56,1 \\
Tidak pernah & 115 & 43,9 \\
\hline Total & 262 & $100 \%$ \\
\hline
\end{tabular}

Tabel 3 menunjukkan sebagian besar responden $(56,1 \%)$ dikelompokkan pernah menderita infeksi saluran pernafasan akut dalam 3 minggu terakhir, dan sebagian kecil $(43,9 \%)$ dikelompokkan tidak pernah menderita infeksi saluran pernafasan akut dalam 3 minggu terakhir.

Analisis bivariat didapatkan nilai $\mathrm{p}$ sebesar 0.001 dengan menggunakan metode Chi- square untuk mencari hubungan tingkat ansietas degan kejadian infeksi saluran pernafasan akut menghasilkan hubungan yang bermakna $(p<0,05)$

\section{PEMBAHASAN}

Distribusi responden dalam penelitian ini terdiri dari 81 (30,9\%) responden laki-laki dan 181 (69\%) responden perempuan. Dari 262 responden didapatkan lebih dari setengah responden (60,3\%) mengalami ansietas. Angka ini lebih tinggi dari pada penelitian yang dilakukan sebelumnya di Fakultas Kedokteran Universitas Andalas oleh Apriady (2013) didapatkan mahasiswa yang mengalami ansietas sebanyak $46,99 \%{ }^{2}$. Hasil yang sama ditemukan pada penelitian yang dilakukan oleh Fuad et al bahwa tingkat ansietas pada mahasiswa kedokteran preklinik di Universiti Putra Malaysia adalah 52\%. ${ }^{4}$ Penelitian sebelumnya dilakukan oleh Wahed dan Hassan (2016) di Universitas Fayom pada 442 mahasiswa kedokteran menunjukkan hasil yang lebih tinggi yaitu didapatkan ansietas sebanyak $64,3 \%{ }^{5}$

Menurut Yadav et al prevalensi ansietas (gangguan cemas) terbanyak didapatkan pada mahasiswa kedokteran tahun pertama dan tahun terakhir. Masalah dalam keluarga, tinggal di kos, mengalami substance abuse dan riwayat depresi dalam keluarga mempengaruhi tingginya kedua kondisi tersebut. $^{14}$

Pada penelitian ini didapatkan mahasiswa yang mengalami infeksi saluran pernafasan akut sebanyak 147 orang (56,1\%). Berdasarkan World Health Organization, Hampir empat juta orang meninggal akibat ISPA setiap tahun, 98\% disebabkan oleh infeksi saluran pernapasan bawah.Tingkat mortalitas sangat tinggi terutama di negara-negara dengan pendapatan per kapita rendah dan menengah. Kejadian penyakit ISPA bervariasi menurut beberapa faktor. Penyebaran dan dampak berkaitan dengan kondisi lingkungan (misalnya polutan udara, kepadatan anggota keluarga, kelembaban, musim, kebersihan, musim, dan temperatur), ketersediaan dan efektivitas pelayanan kesehatan dan langkah pencegahan infeksi untuk mencegah penyebaran (misalnya, vaksin, akses terhadap pelayanan kesehatan,kapasitas ruang isolasi), faktor penjamu (seperti usia, kebiasaan merokok, kemampuan penjamu menularkan infeksi, status kekebalan, status gizi, infeksi sebelumnya),karakteristik patogen (cara penularan, daya tular, virulensi, jumlah dan dosis mikroba). ${ }^{15}$

Stres dipandang sebagai kondisi yang timbul ketika seseorang berhubungan dengan situasi tertentu, dimana suatu "permintaan" melebihi batas kemampuan koping seseorang. Pada orang yang mengalami stres yang mempunyai konsekuensi kondisi yang patologis akan mengganggu respon imun. Penekanan fungsi sistem imun akan menyebabkan peningkatan kerentanan seseorang terhadap terjadinya penyakit infeksi. ${ }^{16}$ 
Stresor pada mahasiswa ini berkaitan dengan kurikulum kedokteran. Lingkungan yang berat dan menuntut menciptakan suatu tekanan tersendiri pada mahasiswa yang dapat berdampak pada tingkat personal atau profesional. Faktor-faktor yang paling membebani selama kuliah bagi mahasiswa kedokteran adalah beberapa jenis ujian, waktu yang sedikit, terlalu banyak konten untuk dipelajari, tertinggal dalam pekerjaan, tuntutan yang saling bertentangan, tidak menyelesaikan pekerjaan pada waktu yang direncanakan dan beban kerja yang berat, banyaknya tuntutan untuk belajar, masalah ekonomi, deprivasi tidur, paparan terhadap masalah dan kematian pasien. $^{17}$

Beberapa stresor lain yang umum ditemukan antara lain penyesuaian diri dengan lingkungan kedokteran, biaya pendidikan yang tinggi, pasien yang sulit, lingkungan pembelajaran yang buruk, banyaknya informasi yang diterima dan perencanaan karir. Stresor ini dapat memicu timbulnya gangguan cemas, depresi, penurunan pencapaian akademis, medical error dan drop out. Masalah kejiwaan pada mahasiswa kedokteran dipengaruhi berbagai faktor seperti jenis kelamin, ras (etnis minoritas), status pernikahan (sudah menikah), buruknya pencapaian akademik, tingkat sosioekonomi, tingkat pendidikan orang tua, hubungan dengan keluarga dan $\mathrm{BMI} \geq 25 \mathrm{~kg} / \mathrm{m} 2$. ${ }^{17,1}$

Berdasarkan uji statistik, didapatkan nilai $p$ sebesar 0.001 dengan menggunakan metode Chisquare untuk mencari hubungan kedua variabel. Hal ini menunjukkan bahwa hipotesis penelitian mengenai adanya hubungan tingkat ansietas dengan infeksi saluran pernafasan akut pada mahasiswa kedokteran angkatan 2015-2016 dapat diterima. Hasil ini disimpulkan karena nilai maksimal $p$ untuk penerimaan hipotesis penelitian adalah 0.05 dengan derajat kesalahan $0.5 \%$.

Penelitian yang dilakukan oleh Dina (2009) didapatkan hasil analisis menunjukkan bahwa terdapat hubungan yang signifikan respon imun dan stres dengan kekambuhan demam tifoid. $^{16} \mathrm{Hal}$ ini memperkuat hipotesa dimana proses inflamasi dapat dipicu oleh keadaan psikologis seseorang. Dalam teori psikoneuroimunologi dikemukan bahwa ide dasar konsep psikoneuroimunologi yaitu status emosi menentukan fungsi sistem kekebalan tubuh dan stress dapat meningkatkan kerentanan tubuh terhadap infeksi dan karsinoma. Karakter, perilaku, pola coping dan status emosi berperan dalam modulasi sistem imun. $^{11}$

\section{SIMPULAN}

Terdapat hubungan yang bermakna antara tingkat ansietas dengan kejadian infeksi saluran pernafasan akut pada mahasiswa kedokteran Universitas Andalas angkatan 2015-2016.

\section{DAFTAR PUSTAKA}

1. Direja, Ade HS. Buku ajar asuhan keperawatan jiwa. Yogyakarta: Nuha Medika; 2011.

2. Apriady T. Prevalensi Ansietas menjelang ujian tulis pada mahasiswa kedokteran FK Unand tahap akademik (skripsi). Padang: Fakultas Kedokteran Universitas Andalas; 2013.

3. Asmadi. Teknik prosedural keperawatan: konsep dan aplikasi kebutuhan dasar klien. Jakarta: Salemba Medika; 2008.

4. Fuad MDF, Lye MS, Ibrahim N, Ismail SIF, Kar PC. Prevalence and risk factors of stress, anxiety and depression among preclinical medical students in Universiti Putra Malaysia in 2014. International Journal of Collaborative Research on Internal Medicine \& Public Health. 2015;7(1):1-12.

5. Wahed WYA, Hassan SK. Prevalence and associated factor of stres, anxiety and depression among Medical Fayom University students. Alexandria Journal of medicine. 2017; 53(1): 77-84.

6. Departemen Kesehatan RI (Depkes RI). Pedoman program pemberantasan penyakit infeksi saluran pernafasan akut untuk penanggulangan premonia pada balita. Jakarta: Depkes RI; 2008.

7. Dinas Kesehatan Kota Padang (Dinkes Kota Padang). Profil penderita ISPA anak tahun 2010. Dinkes Kota Padang; 2013.

8. Suhandayani. Infeksi saluran pernafasan akut dan penanggulangannya. Medan:Universitas Sumatera Utara; 2010

9. Departemen Kesehatan RI (Depkes RI). Buletin epidemiologi ISPA anak. Depkes RI; .2006. 
10. Asmadi. Teknik prosedural keperawatan: konsep dan aplikasi kebutuhan dasar klien. Jakarta: Salemba Medika; 2008.

11. Nurul L. Religiopsikoneuroimunologi Alquran: Studi kolaborasi terapi Al-qur'an dan fungsi otak dalam menghadapi stress. Jurnal Univeristas Gadjah Mada. 2010;18(1):19-28.

12. Wilkins M. Dunbar. White Mayon. Penyakit Infeksi; Edisi ke-6. Jakarta: Erlangga Medical Series;2008.

13. Legiran M, Zaili A, Nadya B . Faktor risiko stres dan perbedaannya pada mahasiswa berbagai angkatan di Fakultas Kedokteran Universitas Muhammadiyah Palembang. Jurnal Kedokteran dan Kesehatan. Palembang: Fakultas Kedokteran Universitas Muhammadiyah Palembang; 2015.

14. Yadav R, Gupta S, Malhotra AK. A cross sectional study on depression, anxiety and their associated factors among medical students in Jhansi, Uttar Pradesh, India. Int $\mathrm{J}$ Community Med Public Health. 2016; 3(5):1209-14.

15. World Health Organization (WHO). Infection prevention and control of epidemic and pandemic prone acute respiratory diseases in health care. WHO Interim Guidelines; 2007.

16. Dina M. Hubungan respon imun dan stress dengan tingkat kekambuhan demam tifoid pada masyarakat di wilayah puskesmas Colomadu Karanganyar (skripsi). Surakarta: Fakultas IImu Keperawatan Universitas Muhammadiyah Surakarta; 2009.

17. Novita A. Masalah kesehatan jiwa pada mahasiswa kedokteran (skripsi). Lampung: Jurusan Pendidikan Dokter Fakultas Kedokteran Universitas Lampung; 2017. 